\title{
PENGARUH KOMUNIKASI NON VERBAL TERHADAP KEPUASAN PELANGGAN
}

\author{
Oleh : \\ lin Kristiyanti \\ efisiensi@uny.ac.id
}

\begin{abstract}
Abstrak
Pelanggan merupakan salah satu asset terbesar organisasi, terlebih dalam organisasi bisnis. Tanpa adanya pelanggan, suatu organisasi lama kelamaan akan mengalami krisis dan bahkan mati. Salah satu unsur agar pelanggan tetap loyal terhadap perusahaan atau organisasi, perlu adanya pelayanan yang berkualitas sehingga dengan demikian kepuasan pelanggan terhadap pelayanan organisasi dapat dirasakan oleh publik.

Hal yang sangat menentukan dalam pelayanan kepada pelanggan yaitu adanya suatu komunikasi. Melalui komunikasi yang baik akan dicapai pengertian yang sama/sepaham antara organisasi dan publiknya dan pada akhirnya publik akan senantiasa mendukung kegiatan-kegiatan organisasi. Bagi organisasi bisnis, dukungan publik terhadap organisasi dalam bentuk menggunakan produk / pelayanan jasa organisasi.

Komunikasi yang dilakukan organisasi dalam bentuk komunikasi verbal maupun komunikasi nonverbal. Komunikasi verbal dilakukan melalui bahasa tulisan dan lisan sedangkan komunikasi non verbal dilakukan melalui bahasa tubuh. Walaupun komunikasi non verbal sering tidak terencana atau kurang terstruktur namun komunikasi non verbal memiliki pengaruh yang lebih besar dari pada komunikasi verbal dalam pelayanan kepada pelanggan. Komunikasi non verbal dapat dipergunakan sebagai sarana untuk menarik pelanggan. Komunikasi non verbal dapat diwujudkan melalui sikap bicara, pandangan mata, cara tersenyum, ekspresi wajah, penampilan, dan bahasa tubuh yang lain. Melalui komunikasi non verbal, pelanggan akan merasakan secara langsung bagaimana pemberi layanan dalam memperlakukan mereka.
\end{abstract}

Kata kunci : komunikasi non verbal, pelayanan pelanggan

\section{Pendahuluan}

Organisasi dalam rangka mencapai tujuannya membutuhkan publik baik internal maupun eksternal. Di antara organisasi dan publiknya terjadi hubungan saling terkait dan saling membutuhkan dengan lingkungannya. Satu-satunya alat organisasi untuk dapat berhubungan dengan publik dilingkungannya adalah dengan kegiatan komunikasi baik secara verbal maupun non verbal.

Komunikasi dapat diartikan sebagai penyampaian suatu pesan atau ide dari seorang komunikator atau penyampai pesan dalam bentuk lambang-lambang tertentu kepada seorang komunikan atau penerima pesan dengan menggunakan suatu media sehingga dapat mudah diterima oleh komunikan dan akhirnya akan ada suatu respon atau feedback dari komunikan tersebut. Lambang-lambang yang dapat digunakan dalam berkomunikasi dapat berbentuk lambang bahasa (komunikasi verbal) dan dalam 
bentuk gerakan-gerakan tubuh, bahasa tubuh (body language) atau sering disebut dengan bahasa non verbal.

\section{Komunikasi Verbal dan Komunikasi Non Verbal}

Menurut Djoko Purwanto (2006:5), komunikasi verbal merupakan salah satu bentuk komunikasi yang lazim digunakan dalam dunia bisnis untuk menyampaikan pesan-pesan bisnis kepada pihak lain secara tertulis (written) maupun secara lisan (oral). Komunikasi verbal menggunakan simbol-simbol yang mempunyai makna yang berlaku umum seperti suara, tulisan atau gambar (Sri Haryani , 2001: 23). Dalam komunikasi verbal ini tidak hanya menyangkut komunikasi tertulis saja, tetapi juga komunikasi lisan.

Sedangkan yang dimaksud dengan komunikasi non verbal adalah kumpulan isyarat ,gerak tubuh, intonasi, suara, sikap dan sebagainya yang memungkinkan seseorang untuk berkomunikasi tanpa menggunakan kata- kata (Bovee \& Thill dalam Sri Haryanti, 2001: 20). Wikipedia Bahasa Indonesia, ensiklopedia bebas (http://id.wikipedia.org/wiki/Komunikasi nonverbal), mendefinisikan komunikasi non verbal sebagai proses komunikasi dimana pesan disampaikan tidak menggunakan katakata. Bentuk komunikasi non verbal menggunakan gerak isyarat; bahasa tubuh; ekspresi wajah dan kontak mata; penggunaan objek seperti pakaian, potongan rambut, dan sebagainya; simbol-simbol; serta cara berbicara seperti intonasi, penekanan, kualitas suara, gaya emosi, dan gaya berbicara. Komunikasi non verbal mempunyai berbagai perbedaan dengan komunikasi verbal, salah satunya adalah bahwa komunikasi non verbal tidak mempunyai bentuk yang tersetruktur dan biasanya bersifat spontanitas sehingga komunikasi non verbal ini lebih sulit dipelajari daripada komunikasi verbal. Namun demikian, meskipun keduanya dapat dibedakan tetapi saling berkaitan erat. Komunikasi lisan dan komunikasi non verbal kadang digunakan secara bersamaan dalam suatu situasi tertentu. Ketika seseorang hendak menyampaikan sesuatu mungkin yang disampaikan melalui komunikasi verbal hanya sebagian dari suatu pesan, sedangkan bagian lainnya, disampaikan melalui tanda-tanda non verbal. Ketika seseorang sedang marah, selain diungkapkan melalui ucapan, seringkali disertai muka merah, mata melotot dan mengepal tangan.

Melalui khttp://www.skylandhacker.co.cc/2009/11/tujuan-komunikasi-nonverbal.htmlomunikasi non verbal orang dapat mengambil suatu kesimpulan tentang berbagai macam perasaan orang, baik rasa senang, benci, cinta, rindu, marah, emosi, tidak setuju, setuju maupun berbagai macam perasaan lainnya. Komunikasi non verbal dalam praktiknya banyak digunakan karena mempunyai kebaikan dan keunggulan yaitu sahih/reliabil (Djoko Purwanto, 2006:9 dan Sri Haryanti, 2001: 20). Hal ini berkaitan dengan tingkat kepercayaan yang tinggi terhadap kebenaran pesan-pesan yang disampaikan dengan menggunakan bahasa isyarat. Secara umum orang akan mudah menipu orang lain dengan menggunakan kata-kata atau tulisan daripada menggunakan 
gerakan tubuh (bahasa isyarat). Komunikasi dengan menggunakan kata-kata akan mudah dikendalikan daripada dengan menggunakan bahasa isyarat (gerakan badan/tubuh) atau ekspresi wajah. Seseorang dapat saja menutup-nutupi kecurangan dengan komunikasi verbal (seperti tertulis), namun ia tidak dapat sepenuhnya menutupi apa yang sedang terjadi pada dirinya karena hal itu tercermin dalam ekspresi wajah. Disamping itu penggunaan komunikasi non verbal lebih efisien dan efektif. Melalui penjelasan yang tidak panjang lebar (secukupnya) pesan sudah dapat dipahami oleh audience.

\section{Tujuan dan Fungsi Komunikasi Non Verbal}

Tujuan adalah sesuatu yang hendak dicapai. Komunikasi non verbal digunakan untuk mencapai tujuan sebagai berikut :

1. Memberikan informasi

2. Mengatur alur suatu percakapan

3. Mengekspresikan emosi

4. Memberi sifat, melengkapi, menentang, atau mengembangkan pesan-pesan verbal.

5. Mengendalikan atau mempengaruhi orang lain.

6. Mempermudah tugas-tugas khusus, ( Bovee dan Thill dalam Djoko Purwanto, 2006:10).

Mengingat komunikasi non verbal efektif dan efisien maka dapat dipakai sebagai pelengkap dalam komunikasi verbal ketika organisasi memberikan pelayanan kepada pelanggan. Pemberi layanan dapat menunjukkan empati, perhatian dan sopan santun sehingga pelanggan merasa dihargai, diperhatikan dan dilayani dengan baik. Misal ketika memberi contoh cara menggunakan alat akan lebih efektif jika tidak hanya memberikan petunjuk lisan namun dilengkapi dengan gerakan cara penggunaannya.

Komunikasi non verbal membantu komunikator agar informasi yang disampaikan dapat diterima secara benar. Hal ini dikarenakan komunikasi non verbal dapat berfungsi sebagai: 1) repetisi, 2) substitusi, 3) kontradiksi, 4) aksentuasi, dan 5) komplemen (http://id.wikipedia.org/wiki/Komunikasi nonverba)l. Repetisi berarti mengulangi komunikasi verbal, misal menganggukan kepala ketika mengatakatan setuju. Substitusi berarti menggantikan perilaku verbal, misal guru memberi perintah diam tanpa sepatah katapun. Kontradiksi berarti membantah senyum mencibir. Aksentuasi berarti memperteguh, misal nada suara yang pelan/keras. Komplemen berarti meregulasi komunikasi verbal, misal ketika guru melihat jam berkali-kali sebagai tanda pelajaran segera usai.

Komunikasi verbal dapat dipakai sebagai pendukung dalam memberikan pelayanan kepada pelanggan atau malahan sebaliknya pelanggan dapat menangkap kesan yang kurang baik dari bahasa tubuh pemberi layanan Berkenaan dengan itu pemberi layanan 
perlu mempelajari tentang bahasa tubuh ini dan secara sadar serta hati-hati dalam menggunakannya ketika memberikan pelayanan kepada pelanggan.

\section{Jenis-jenis Komunikasi Non Verbal}

Pada dasarnya komunikasi digunakan untuk menciptakan atau meningkatkan aktifitas hubungan

antara manusia atau kelompok. Untuk itu organisasi dapat memilih jenis-jenis komunikasi non verbal agar memberi kesan tersendiri bagi pelanggannya. Organisasi dapat memilih jenis-jenis komunikasi non verbal berikut: 1) komunikasi objek, 2) sentuhan, 3) konemik, 4) gerakan tubuh, 5) proxemik, 6) vokalik, dan 7) lingkungan.

Komunikasi objek yang sering digunakan organisasi adalah penggunaan pakaian seragam karena sebagai identitas organisasi, pemakain seragam menyampaikan kesan menghargai public dan professional. Sedangkan sentuhan (cara bersalaman, tepukan, dil) dapat menyampaikan pesan dan kesan yang menarik, orang yang bersalaman sekedar memegang tangan memberi kesan "dingin" atau kurang perhatian. Konemik merupakan penggunaan waktu/durasi dalam memberikan pelayanan, misal ketepatan waktu dan kecepatan dalam memberikan pelayanan juga merupakan komunikasi non verbal yang perlu diperhatikan organisasi. Gerakan tubuh (kontak mata, ekspresi wajah, isyarat, dan sikap tubuh) juga dapat dipakai untuk menarik pelanggan agar merasa dilayani dengan baik. Organisasi dapat mengunakan jenis Proxemik ketika berkomunikasi dengan pelanggan, yaitu dengan mengatur tempat atau lokasi serta posisi. Melalui pengaturan posisi ini pelanggan akan merasakan keakraban, penghargaan, dan perhatian dari pemberi layanan. Sedangkan vokalik yang diartikan sebagai nada bicara, nada suara, keras atau lemahnya suara, kecepatan berbicara, kualitas suara, intonasi, dan lain-lain juga sangat mempengaruhi kesan pelanggan terhadap pelayanan yang diberikan organisasi. Demikian pula lingkungan sebagai salah satu jenis komunikasi non verbal dapat pula digunakan untuk menyampaikan pesanpesan tertentu, seperti warna, kerapian, kebersihan, temperatur, dan penerangan.

Organisasi dapat menggunakan berbagai jenis komunikasi non verbal tersebut di atas agar pelanggan dapat menangkap kesan positif bagi organisasi.

\section{Pengaruh Komunikasi Non Verbal Terhadap Pelayanan Pelanggan}

Apabila pelaku organisasi dapat belajar mengelola pesan yang dibuat dengan bahasa isyarat, karakteristik atau ekspresi wajah, suara dan penampilan, maka seseorang akan dapat melakukan komunikasi dengan baik. Bahasa non verbal dapat dipergunakan sebagai alat atau sarana ketika organisasi berkomunikasi dengan pelanggannya.

Pelanggan merupakan asset yang sangat besar bagi organisasi. Pelanggan dapat diartikan masyarakat pada umumnya yang potensial membutuhkan produk dan 
jasa dan berpotensi untuk melakukan pembelian (Oka A. Yoeti, 1999:11) . Sebagai organisasi bisnis, untuk menjaga dan mempertahankan pelanggannya agar selalu tetap setia salah satunya adalah dengan memberikan pelayanan yang semaksimal mungkin kepada pelanggan. Pelaku organisasi sebaiknya selalu berusaha untuk dapat melayani pelanggan dengan sebaik-baiknya. Untuk memberikan pelayanan kepada pelanggan perlu diingat hal-hal sebagai berikut:

1. Pelaku organisasi dapat memposisikan diri sebagai pelanggan

Dengan pelaku organisasi dapat memposisikan diri sebagai pelanggan, maka mereka akan dapat paham apa yang diinginkan oleh pelanggan misalkan pelanggan ingin dilayani dengan ramah, pelanggan ingin dilayani dengan semangat, cepat, dan tepat, pelanggan dapat dibantu menyelesaikan masalahnya dengan baik dan sebagainya.

2. Pelaku organisasi haruslah mempunyai anggapan bahwa pelanggan atau Customer adalah boss/ pimpinan mereka.

Pelanggan/customer dapat dikatakan bahwa mereka adalah boss/pimpinan mereka karena dengan pelanggan/customer dapat menaikkan jabatan kita, dapat mempromosikan kita dan bahkan dapat memecat kita pula secara tidak langsung. Karena dengan perlakuan pelaku organisasi yang kurang atau bahkan tidak baik, maka pelanggan tersebut akan menyampaikan kepada pihak manajemen perusahaan.

3. Pelaku organisasi harus mempunyai pemikiran bahwa pelanggan adalah laba organisaasi.

Pelanggan dapat memberikan laba yang besar kepada organisasi/perusahaan, karena apabila organisasi/perusahaan tidak mempunyai pelanggan, maka produk atau jasa yang dijual tidak akan banyak yang terjual atau di beli sehingga dampaknya organisasi/perusahaanpun tidak akan mendapatkan laba bahkan akan selalu merugi.

Dengan memposisikan pelanggan sebagai diri sendiri, bos/pimpinan, dan laba maka dapat memotivasi organisasi untuk dapat melakukan komunikasi dengan baik kepada para pelanggan. Disamping komunikasi verbal, komunikasi non verbal dapat dipergunakan sebagai alat efektif untuk menarik pelanggan karena dapat memberi citra positif bagi organisasi yang dapat mempengaruhi kredibilitas organisasi atau perusahaan.

Beberapa hal yang perlu diperhatikan dalam berkomunikasi nonverbal agar pelanggan merasa dapat dilayani dengan baik adalah :

1. Penampilan pribadi

Penampilan pribadi ini sangat penting dalam pelayanan kepada pelanggan.

Pelaku organisasi yang professional akan dapat memberikan penampilan diri 
yang baik dan menyenangkan sehingga pelanggan akan merasa senang. Berpakain rapi dan sikap sopan akan mendukung pelanggan merasa dihormati dan diperhatikan.

2. Ekspresi wajah

Wajah merupakan tempat utama untuk mengekspresikan emosi dan perasaan seseorang, demikian juga dengan mata, mata dapat menunjukkan perhatian dan minat seseorang terhadap sesuatu hal, untuk dapat mempengaruhi orang lain dan untuk mengatur interaksi antara komunikator dengan audience. Perlu berhatihati dalam mengekspresikan wajah saat berkomunikasi dengan pelanggan,terlebih lagi terhadap pelanggan yang komplin. Misalnya apakah mata akan berputar-putar, wajah cemberut, ataukah tersenyum masam. Dalam pelayanan kepada pelanggan harus mempunyai ekspresi wajah yang tenang, perhatian, tulus, ramah dan menarik

3. Sikap tubuh

Gerakan tubuh dan posisi tubuh juga dapat digunakan untuk menunjukkan emosi dan sikap seseorang. Dengan cara berdiri atau duduk tegak dapat menunjukkan sikap perhatian kepada pelanggan. Apabila melayani pelanggan dengan bersandar malas atau duduk membungkuk, maka akan terkesan tidak mempunyai perhatian terhadap pelanggan. Mempertahankan sikap tubuh terbuka, dan tidak menantang. Berdiri dengan jarak yang cukup untuk memberikan ruang gerak bagi pelanggan dan jangan mengerumininya.

4. Gerakan

Pelanggan akan merasa senang apabila dapat dilayani atau direspon dengan cepat. Gerakan yang lambat akan dapat menjengkelkan seorang pelanggan.

5. Gerak isyarat atau sikap

Sikap tangan menyilang umumnya diinterprestasikan sebagai sikap tertutup dan tidak bersedia mendengarkan,. Apabila sedang berkomunikasi dengan pelanggan sebaiknya dihindari menyilangkan tangan atau menopang kepala dengan tangan. $\mathrm{Hal}$ ini menunjukkan bahwa pelanggan merasa didengarkan dan tidak memiliki prasangka apapun.

6. Nada suara

Dalam melayani pelanggan nada suara sangat penting karena sikap seseorang dapat diproyeksikan melalui nada suara dan bahasa tubuh. Orang akan lebih menanggapi terhadap bagaimana seseorang mengatakan sesuatu dari pada apa yang dikatakan. Bila nada suara terkesan menjengkelkan, tidak sabar, atau merendahkan, pelanggan akan kecewa dan bahkan marah dengan pelayanan yang diterimanya. Apabila nada suara terkesan penuh percaya diri, maka pelanggan akan yakin bahwa apa yang disampaikan sangat dipahami sehingga hal ini untuk memudahkan dalam melayaninya. Dalam melayani pelanggan 
berbicara dengan tenang, , tegas dengan nada suara yang lembut dan menyejukkan tidak selalu dengan nada yang tinggi (Rebecca L. Morgan, 2005: 21).

Salah satu contoh penggunaan komunikasi non verbal dalam melayani pelanggan adalah pada waktu pelanggan datang pertama kali ke organisasi atau perusahaa yaitu dengan menyapa pelanggan tersebut. Banyak komunikasi yang terjadi selama beberapa detik pertama yang dilakukan dengan pelanggan. Sedangkan perasaan dan persepsi yang terbentuk sering berlangsung untuk selamanya

Menurut Ron Willingham (2003:21), bahwa kontak mata, sikap, dan kemampuan seseorang memecahkan keasyikan, mengabaikan yang lain dan hanya mendengarkan dengan penuh perhatian seseorang di depan kita dengan segera akan mempengaruhi orang tersebut. Hal ini tidak dapat dijelaskan dengan logika, karena terjadi secara emosional.

Komunikasi non verbal, bahasa tubuh, dan ekspresi muka seseorang dengan cepat menciptakan kesan di bawah sadar pada pelanggan bahwa pelanggan dapat mengatakan pada dirinya sendiri secara tidak sadar bahwa pelanggan senang dengan pelayanan orang tersebut. Mengingat komunikasi non verbal sangat penting bagi organisasi karena organisasi sebaiknya memiliki kepentingan untuk memberikan semacam pedoman komunikasi non verbal yang harus dilakukan karyawannya ketika melayani pelanggan dan memformalkannya baik melalui sikap, perilaku, penataan lingkungan kantor, dan kecepatan pelayanan sehingga dengan demikian karyawan dan organisasi memiliki kompetensi, kemampuan dalam menerapkan komunikasi non verbal ketika memberikan pelayanan kepada pelanggan.

Komunikasi non verbal yang dilakukan secara tepat, akan memberikan pengaruh pada kepuasan pelanggan. Kepuasan pelanggan biasanya diukur dari sejauhmana organisasi dapat memenuhi kebutuhan pelanggannya. Pelanggan biasanya mengharapkan pelayanan yang berkualitas, yang biasanya diukur dari kecepatan pelayanan, pelayanan yang responsive, empati, dan lingkungan pelayanan (tangibility).

Komunikasi non verbal yang dioperasionalkan melalui dimensi kumpulan isyarat, gerakan tubuh (kontak mata, ekspresi wajah), sentuhan, kedekatan, dan lingkungan yang baik akan sangat efektif atau mempunyai hubungan yang kuat dalam menciptakan kepuasan pelanggan. Kepuasan pelanggan yang dioperasionalkan melalui indikator kecepatan, empati, responsive, dapat meningkat karena pemberi layanan menerapkan komunikasi non verbal pada saat proses pemberian layanan. 